\title{
EVALUATION OF WIND EROSION CONTROL PRACTICES AT A PHOTOVOLTAIC POWER STATION WITHIN A SANDY AREA OF NORTHWEST, CHINA
}

\author{
Chun Wang ${ }^{1}$, Robert L. Hill ${ }^{2}$, Ch Bu ${ }^{1}$, Bingyin $\mathrm{Li}^{1}$, Fang Yuan ${ }^{1}$, Yanzhe Yang ${ }^{3}$, Senpeng \\ Yuan $^{1}$, Zhenshi Zhang ${ }^{4}$, Yongxiang $\mathrm{Cao}^{4}$, and Kankan Zhang ${ }^{5}$ \\ ${ }^{1}$ Northwest Agriculture and Forestry University \\ ${ }^{2}$ University of Maryland Center for Environmental Science \\ ${ }^{3}$ Institute of Soil and Water Conservation Chinese Academy of Sciences and Ministry of \\ Water Resources \\ ${ }^{4}$ Northwest Engineering Corporation Limited of Power China \\ ${ }^{5}$ Shaanxi Lvtuo Eco-environment Engineering Co., Ltd.
}

May 5, 2020

\begin{abstract}
The widespread construction of photovoltaic (PV) power stations within northwest China poses an environmental threat because of severe wind erosion and land degradation attributed to unique wind control issues caused by the power stations. In this study, various engineering (E), plant (V), and biocrust (B) treatments were evaluated for their effectiveness in the reduction of wind erosion. The placement of solar panels with wide wind inlets and narrow wind outlets caused wind velocity reductions at the inlet that sharply increased at the outlet and formed distinct zones of deflation, direct shear abrasion (DSA), and deposition. The engineering treatments reduced the wind velocities and sand transport rates, in comparison to the control with E4 (DSA zone + a gravel/deposition zone + red clay) being the most effective with an $87 \%$ reduction in the total sand transport rate. Both plant treatments V1 (Sedum aizoon L.) and V2 (Pennisetum alopecuroides (L.) Spreng) increased the aerodynamic roughness, and decreased the sand transport rates and the sand erosion-deposition budget under or between the solar panels. Treatment B2 (moss crust) decreased the sand transport rate and sand erosion-deposition budget under the solar panels in comparison to the control. All the treatments had effects on reducing wind erosion, and we strongly recommend the use of moss crust, gravel mulch, and red clay mulch in the deflation zones, DSA zones, and deposition zones, respectively, to control the severe wind erosion at these PV power stations located in sandy areas.
\end{abstract}

\section{Hosted file}

manuscript.docx available at https://authorea.com/users/302323/articles/432502-evaluationof-wind-erosion-control-practices-at-a-photovoltaic-power-station-within-a-sandy-areaof-northwest-china

\section{Hosted file}

Tables.docx available at https://authorea.com/users/302323/articles/432502-evaluation-ofwind-erosion-control-practices-at-a-photovoltaic-power-station-within-a-sandy-area-ofnorthwest-china

\section{Hosted file}


Figure 1.doc available at https://authorea.com/users/302323/articles/432502-evaluation-ofwind-erosion-control-practices-at-a-photovoltaic-power-station-within-a-sandy-area-ofnorthwest-china

\section{Hosted file}

Figure 2.doc available at https://authorea.com/users/302323/articles/432502-evaluation-ofwind-erosion-control-practices-at-a-photovoltaic-power-station-within-a-sandy-area-ofnorthwest-china

\section{Hosted file}

Figure 3.doc available at https://authorea.com/users/302323/articles/432502-evaluation-ofwind-erosion-control-practices-at-a-photovoltaic-power-station-within-a-sandy-area-ofnorthwest-china

\section{Hosted file}

Figure 4.doc available at https://authorea.com/users/302323/articles/432502-evaluation-ofwind-erosion-control-practices-at-a-photovoltaic-power-station-within-a-sandy-area-ofnorthwest-china

\section{Hosted file}

Figure 5.doc available at https://authorea.com/users/302323/articles/432502-evaluation-ofwind-erosion-control-practices-at-a-photovoltaic-power-station-within-a-sandy-area-ofnorthwest-china

\section{Hosted file}

Figure 6.doc available at https://authorea.com/users/302323/articles/432502-evaluation-ofwind-erosion-control-practices-at-a-photovoltaic-power-station-within-a-sandy-area-ofnorthwest-china

\section{Hosted file}

Figure 7.doc available at https://authorea.com/users/302323/articles/432502-evaluation-ofwind-erosion-control-practices-at-a-photovoltaic-power-station-within-a-sandy-area-ofnorthwest-china

\section{Hosted file}

Figure 8.doc available at https://authorea.com/users/302323/articles/432502-evaluation-ofwind-erosion-control-practices-at-a-photovoltaic-power-station-within-a-sandy-area-ofnorthwest-china

\section{Hosted file}

Figure 9.doc available at https://authorea.com/users/302323/articles/432502-evaluation-ofwind-erosion-control-practices-at-a-photovoltaic-power-station-within-a-sandy-area-ofnorthwest-china 